\title{
Inhibitory activity of root canal irrigants against Candida albicans, Enterococcus faecalis and Staphylococcus aureus
}

\section{Tatiana Kelly da Silva Fidalgo(a) Roberta Barcelos ${ }^{(b)}$ \\ Maristela Barbosa Portela(c) Rosangela Maria de Araújo Soares $^{(\mathrm{d})}$ \\ Rogério Gleiser(c) \\ Fernando Costa e Silva-Filho(e)}

(a) School of Dentistry of Rio de Janeiro, Federal University of Rio de Janeiro, Rio de Janeiro, RJ, Brazil.

(b) Department of Specific Formation, School of Dentistry, Fluminense Federal University, Nova Friburgo, RJ, Brazil.

(c) Department of Pediatric Dentistry and Orthodontics, School of Dentistry, Federal University of Rio de Janeiro, Rio de Janeiro, RJ, Brazil.

(d) Professor Paulo de Goes Institute of Microbiology, University of Rio de Janeiro, Rio de Janeiro, RJ, Brazil.

(e) Carlos Chagas Filho Biophysics Institute, Federal University of Rio de Janeiro, Rio de Janeiro, RJ, Brazil.

\section{Corresponding author: \\ Tatiana Kelly da Silva Fidalgo \\ Rua Joaquim Távora 244/202 - Icarai \\ Niterói - RJ - Brazil \\ CEP: 24230-541 \\ E-mail: tatianakkelly@yahoo.com.br}

Received for publication on Feb 06, 2010 Accepted for publication on Aug 09, 2010

\begin{abstract}
The present study evaluated the antimicrobial activity of three root canal irrigants against Enterococcus faecalis, Candida albicans, and Staphylococcus aureus. These microorganisms were incubated in the presence of citric acid (6 and 10\%), EDTA (17\%), and $\mathrm{NaOCl}(0.5,1.0$, 2.5 , and $5.25 \%)$. Agar diffusion tests were performed and redox indicator resazurin was used to evaluate the inhibitory effect of the irrigants on the metabolic activity of these microorganisms. The mean diameters of the inhibition zones for the C. albicans cultures were $11.6 \mathrm{~mm}$ (17\% EDTA), $5.5 \mathrm{~mm}$ (0.5\% NaOCl), $12.9 \mathrm{~mm}$ (1\% NaOCl), $22.1 \mathrm{~mm}$ $(2.5 \% \mathrm{NaOCl})$, and $28.5 \mathrm{~mm}(5.25 \% \mathrm{NaOCl})$. The mean diameters of the inhibition zones for E. faecalis were $2.8 \mathrm{~mm}(1 \% \mathrm{NaOCl}), 5.4 \mathrm{~mm}$ $(2.5 \% \mathrm{NaOCl})$, and $8.3 \mathrm{~mm}(5.25 \% \mathrm{NaOCl})$. For $S$. aureus, the mean values were $8.0 \mathrm{~mm}$ (17\% EDTA), $3.0 \mathrm{~mm} \mathrm{(1 \%} \mathrm{NaOCl),} 8.8 \mathrm{~mm}(2.5 \%$ $\mathrm{NaOCl})$, and $10.0 \mathrm{~mm}(5.25 \% \mathrm{NaOCl})$. Most of the irrigant solutions presented effective antimicrobial activity against C. albicans. A high inhibitory effect on the metabolic activity of E. faecalis was detected when the microorganisms were incubated with $17 \%$ EDTA. The same result was reached when $S$. aureus was incubated in the presence of $\geq 2.5 \%$ $\mathrm{NaOCl}$. Altogether, these results indicate that $2.5 \%$ and $5.25 \% \mathrm{NaOCl}$ are microbicides against $S$. aureus while $0.5 \%$ and $1 \% \mathrm{NaOCl}$ are only microbiostatic against the tested bacteria. The $6 \%$ and $10 \%$ citric acid as well as $17 \%$ EDTA did not affect the viability of any of the assayed microorganisms.
\end{abstract}

Descriptors: Candida albicans; Enterococcus faecalis; Staphylococcus aureus; Root Canal Irrigants.

\section{Introduction}

Microorganisms are the major causative factor associated with endodontic treatment failure. ${ }^{1,2}$ The success of endodontic treatment depends on the reduction or elimination of bacteria present in the root canal system. Residual pulpal tissue, bacteria, and dentine debris may persist in the irregularities of root canal systems, even after meticulous mechanical preparation. ${ }^{3}$ Therefore, irrigant solutions should be used in combination with canal preparation. ${ }^{4-6}$

Root canal irrigants are used during chemomechanical procedures not only as antimicrobial agents but also to flush out loose debris, to lubricate the dentinal walls, and to dissolve organic compounds in the 
canal. ${ }^{7,8}$ Chemomechanical preparation is one of the most important phases of endodontic treatment and irrigants such as sodium hypochlorite $(\mathrm{NaOCl})$, citric acid, and ethylene diamine tetra-acetic acid (EDTA) are commonly used. The efficacy of these procedures also depends upon the vulnerability of the species involved. ${ }^{9}$

Many in vitro studies relate the antimicrobial activity of root canal irrigants against microorganisms, but studies on the metabolic activity of microorganisms after contact with these irrigants was not found in the literature. ${ }^{5,6}$ Therefore, this study first evaluated the effectiveness of $\mathrm{NaOCl}(0.5,1,2.5$, 4 , and $5.25 \%$ ), EDTA (17\%), and citric acid (6 and $10 \%)$ against Enterococcus faecalis, Candida albicans, and Staphylococcus aureus, and then assessed their metabolic activities under the same conditions.

\section{Material and Methods Microorganisms}

The following microorganisms and their related ATCC strains were used throughout: Staphylococcus aureus (ATCC 6538), Enterococcus faecalis (ATCC 29212) and Candida albicans (ATCC 10231). All microorganisms were grown in BHIagar medium (Difco, Rio de Janeiro, RJ, Brazil) supplemented with $10 \%$ sheep blood $\left(24 \mathrm{~h}, 37^{\circ} \mathrm{C}\right.$, $5 \% \mathrm{CO}_{2}$ atmosphere or in anaerobiosis). The microorganisms were then collected with a Drigalsky spatula for standardization of quantities collected and resuspended in sterile $0.01 \mathrm{M}$ phosphate buffer $\mathrm{pH}$ 7.2, containing $0.15 \mathrm{M} \mathrm{NaCl}$ (PBS pH 7.2). The quantity of all microorganisms was adjusted using McFarland's scale (McFarland Standard no. 0.5) and spectrophotometrically adjusted to $10^{5} \mathrm{CFU}$. $\mathrm{ml}^{-1}$ through optical density measurement at $600 \mathrm{~nm}$ $\left(\mathrm{OD}_{600}\right)$.

\section{Root canal irrigants}

The root canal irrigants used were: citric acid (6 and 10\% - VETEC, Rio de Janeiro, RJ, Brazil), EDTA (17\% - Biodinâmica, Rio de Janeiro, RJ, Brazil), and $\mathrm{NaOCl}(0.50,1.00,2.50$, and 5.25\% - Fórmula \& Ação, São Paulo, SP, Brazil). All of these compounds were diluted in sterile PBS pH 7.2.

\section{Agar Diffusion Test (ADT)}

For this test, nitrocellulose membranes $(13.0 \mathrm{~mm}$ - Catalogue No GSWP04700; Millipore Co., Billerica, MA, USA) impregnated with the root canal irrigants $(30 \mu \mathrm{l}$ each), described above, were placed on the top of $S$. aureus, E. faecalis, and C. albicans $\left(0.1 \mathrm{ml}, 10^{5}\right.$ CFU. $\mathrm{ml}^{-1}$, resuspended in PBS $\mathrm{pH}$ 7.2) homogeneously spread onto separated Petri dishes (10 cm diameter) containing BHI agar medium. The microorganism cultures were kept in an incubator $\left(24 \mathrm{~h}, 37^{\circ} \mathrm{C}, 5 \% \mathrm{CO}_{2}\right.$ atmosphere or in anaerobiosis) before measuring the growth inhibition zones. Cell viability (negative control) was determined by incubating the bacteria with Bactrin (Sulfametoxazol-trimetoprima - RJ 0401, Roche, Rio de Janeiro, RJ, Brazil) and the fungus with Fluconazole (Ache, Rio de Janeiro, RJ, Brazil); and the positive controls consisted in incubation of the same microorganisms in PBS pH 7.2. The inhibition zone limit was measured from the edge of the membrane disk to the end of the inhibition zone. A millimeter marking rule was used for this purpose. ${ }^{9}$ All assays were done in triplicate.

\section{Metabolic activity}

In order to collect a standard quantity of samples submitted to ADT, the authors developed the following method. Briefly, micropipette tips (S11110006; TipOne; Blakelands, MK, UK) with $15 \mathrm{~mm}$ cut off from the thinner end were used to collect a fixed (standard) quantity of sample from the inhibition zone. For each sample collection, the tip was inserted $1 \mathrm{~mm}$ from the nitrocellulose membrane, and then the collected sample was resuspended in PBS $(300 \mu \mathrm{l})$. Equivalent selection points to collect the microorganism are essential to maintain the same parameters for all microorganisms studied. To adjust the quantity of microorganisms to be tested, $\mathrm{OD}_{530}$ of the samples was taken using PBS as a blank solution. The $\mathrm{OD}_{530}$ of all samples was $\sim 0.5$.

Microorganisms $(100 \mu \mathrm{l})$, in the above conditions, were reacted $\left(3 \mathrm{~h}, 37^{\circ} \mathrm{C}\right)$ with resazurin ${ }^{10}$ (30 $\mu 1$ - R7017, Sigma-Aldrich Corp. St. Louis, MO, USA), a redox potential indicator, in 96 plastic well plates (Millipore, Bedford, MA, USA). The reactions were carried out in triplicate and read spectro- 
metrically at $530 \mathrm{~nm}\left(\mathrm{OD}_{530}\right)$.

\section{Statistical analysis}

The data were analyzed by the SPSS 16.0 (SPSS Inc, Chicago, IL, USA) software using the analysis of variance $($ ANOVA) and the Tukey $(\mathrm{p}<0.05)$ test.

\section{Results}

The data summarized in Table 1 show that incubation of the microorganisms with citric acid $(6$ or $10 \%$ ) did not inhibit their growth, since inhibition zones were not apparent (data not shown). Neither $17 \%$ EDTA nor $0.5 \% \mathrm{NaOCl}$ inhibited the growth of Enterococcus fecalis, and the latter did not have any effect on Staphylococcus aureus either. In contrast, $17 \%$ EDTA presented activity against both Candida albicans and Staphylococcus aureus. $\mathrm{NaOCl}$ at higher concentrations (1, 2.5, and 5.25\%) presented inhibitory activity against all microorganisms tested. Furthermore, the antimicrobial effect of $5.25 \% \mathrm{NaOCl}$ was comparable to the results presented by the negative controls (Bactrim and Fluconazole). EDTA (17\%) presented higher antimicrobial activity than $0.5 \% \mathrm{NaOCl}$, when tested against Candida albicans and Staphylococcus aureus. The effect of EDTA (17\%) on Candida albicans was similar to that exhibited by $1 \% \mathrm{NaOCl}$, but more effective on Staphylococcus aureus. Higher concentrations of $\mathrm{NaOCl}(2.5$ and $5.25 \%)$ were more effective on Candida albicans than 17\% EDTA, however their activities on Staphylococcus aureus were similar.

EDTA $(17 \%)$ presented more effective antimicrobial activity than citric acid (6 and 10\%) against all assayed microorganisms. It can also be noted that the effectiveness of $\mathrm{NaOCl}$ on E. faecalis was dosedependent. Furthermore, $5.25 \% \mathrm{NaOCl}$ was lethal to all assayed microorganisms (Table 2).

To evaluate the microbicidal or microbiostatic activity of the root canal irrigants studied here, redox analyses of samples taken from the inhibition zones were carried out. Candida albicans and Enterococcus faecalis metabolic activities were detected in all tested root canal irrigants (that formed inhibition zones). However, no metabolic activity of Staphylococcus aureus was detected for $2.5 \%$ and $5.25 \% \mathrm{NaOCl}$ (Table 3 and Graph 1).

\section{Discussion}

Chemomechanical procedure plays an important role in reducing microorganisms in the root canal. ${ }^{11}$ Previous studies have shown that irrigation with $0.5 \% \mathrm{NaOCl}$ eliminated bacteria in $50 \%$ to $75 \%$ of infected root canals at the end of the first treatment. ${ }^{12}$ In the present study, only Candida albicans was sensitive to $0.5 \% \mathrm{NaOCl}$. However, all microbial species tested were sensitive to $5.25 \% \mathrm{NaOCl}$. EDTA is an auxiliary substance that has a chelating action, biocompatibility with the periapical tissues ${ }^{13}$ and optimal cleansing abilities. ${ }^{14}$ In the current study, 17\% EDTA showed a superior antimicrobial effect in the inhibition zone test against Candida albicans when compared to $0.5 \% \mathrm{NaOCl}$.

Enterococcus faecalis is considered one of the most resistant species in the oral cavity and a possible cause of failure in root canal treatments. It can survive after instrumentation and irrigation with $\mathrm{NaOCl}$ up to $2.5 \% .{ }^{15}$ The findings of the present study showed that $5.25 \% \mathrm{NaOCl}$ had a significantly better performance than $2.5 \% \mathrm{NaOCl}$ against this

Table 1 - Inhibition zones ( $\mathrm{mm}$ ) detected when microorganisms were cultured in the presence of different concentrations (\%) of citric acid, EDTA or $\mathrm{NaOCl}$.

\begin{tabular}{|c|c|c|c|c|c|c|c|c|c|}
\hline \multirow[b]{2}{*}{ Microorganism } & \multicolumn{9}{|c|}{ Irrigant solution } \\
\hline & $\begin{array}{c}\text { 6\% Citric } \\
\text { acid }\end{array}$ & $\begin{array}{c}10 \% \text { Citric } \\
\text { acid }\end{array}$ & $\begin{array}{l}17 \% \\
\text { EDTA }\end{array}$ & $\begin{array}{c}0.5 \% \\
\mathrm{NaOCl}\end{array}$ & $\begin{array}{c}1.0 \% \\
\mathrm{NaOCl}\end{array}$ & $\begin{array}{c}2.5 \% \\
\mathrm{NaOCl}\end{array}$ & $\begin{array}{l}5.25 \% \\
\mathrm{NaOCl}\end{array}$ & $\begin{array}{l}\text { Positive } \\
\text { Control }\end{array}$ & $\begin{array}{l}\text { Negative } \\
\text { Control* }\end{array}$ \\
\hline C. albicans & - & - & 11.6 & 5.5 & 12.9 & 22.1 & 28.4 & - & 29.5 \\
\hline Enterococcus faecalis & - & - & - & - & 2.8 & 5.4 & 8.3 & - & 6.3 \\
\hline Staphylococcus aureus & - & - & 8.0 & - & 3.0 & 8.8 & 10.0 & - & 12.2 \\
\hline
\end{tabular}

*For negative control E. faecalis and S. aureus microorganisms were treated with Bactrin, and C. albicans was treated with Fluconazole. 
Table 2 - A comparative statistical analysis of the data obtained from assays carried out to generate inhibition zones by incubating the microorganisms Staphylococcus aureus (SA), Enterococcus faecalis (EF), and Candida albicans (CA) with different concentrations (\%) of canal irrigant solutions

\begin{tabular}{|c|c|c|c|c|c|c|c|c|c|c|}
\hline \multirow{2}{*}{\multicolumn{2}{|c|}{ Microorganism }} & \multicolumn{9}{|c|}{ Irrigant solution } \\
\hline & & \multirow{2}{*}{$\begin{array}{c}\text { C (-) Bac/ } \\
\text { Flu } \\
- \\
- \\
-\end{array}$} & \multirow{2}{*}{$\begin{array}{l}C(+) \text { PBS } \\
<0.001^{*} \\
<0.001^{*} \\
<0.001^{*}\end{array}$} & \multirow{2}{*}{$\begin{array}{c}6 \% \text { citric } \\
\text { acid }\end{array}$} & \multirow{2}{*}{$\begin{array}{c}10 \% \text { citric } \\
\text { acid }\end{array}$} & \multirow{2}{*}{$\begin{array}{r}17 \% \text { EDTA } \\
0.003^{*} \\
<0.001^{*} \\
<0.001^{*} \\
\end{array}$} & \multirow{2}{*}{$\begin{array}{c}0.5 \% \\
\mathrm{NaOCl} \\
<0.001^{*} \\
<0.001^{*} \\
<0.001^{*}\end{array}$} & \multirow{2}{*}{$\begin{array}{c}\begin{array}{c}1.0 \% \\
\mathrm{NaOCl}\end{array} \\
0.005^{*} \\
<0.001^{*} \\
<0.001^{*}\end{array}$} & \multirow{2}{*}{$\begin{array}{c}2.5 \% \\
\mathrm{NaOCl} \\
0.356 \\
0.012^{*} \\
<0.001^{*}\end{array}$} & \multirow{2}{*}{$\begin{array}{r}5.25 \% \\
\mathrm{NaOCl} \\
1.000 \\
0.001^{*} \\
<0.001^{*}\end{array}$} \\
\hline $\begin{array}{c}\mathrm{C}(-) \mathrm{Bac} / \\
\text { Flu }\end{array}$ & $\begin{array}{l}\mathrm{CA} \\
\mathrm{EF} \\
\mathrm{SA}\end{array}$ & & & & & & & & & \\
\hline$C(+)$ PBS & $\begin{array}{l}\mathrm{CA} \\
\mathrm{EF} \\
\mathrm{SA}\end{array}$ & $\begin{array}{l}<0.00 \\
<0.00 \\
<0.00\end{array}$ & - & $\begin{array}{l}1.000 \\
1.000 \\
1.000\end{array}$ & & & & $\begin{array}{c}0.028^{*} \\
<0.001^{*} \\
0.266\end{array}$ & $\begin{aligned} & 0.001^{*} \\
< & 0.001^{*} \\
& 0.157\end{aligned}$ & $\begin{aligned} &<0.001^{*} \\
&<0.001^{*} \\
& 0.581\end{aligned}$ \\
\hline $\begin{array}{c}\text { 6\% Citric } \\
\text { acid }\end{array}$ & $\begin{array}{l}\mathrm{CA} \\
\mathrm{EF} \\
\mathrm{SA}\end{array}$ & $\begin{array}{l}1.000 \\
1.000 \\
1.000\end{array}$ & & $\begin{array}{l}- \\
- \\
-\end{array}$ & & & & $\begin{array}{c}0.028^{*} \\
<0.001^{*} \\
0.266\end{array}$ & $\begin{aligned} & 0.001^{*} \\
< & 0.001^{*} \\
< & 0.001^{*}\end{aligned}$ & $\begin{aligned} & 0.001^{*} \\
< & 0.001^{*} \\
< & 0.001^{*}\end{aligned}$ \\
\hline $\begin{array}{c}10 \% \text { Citric } \\
\text { acid }\end{array}$ & $\begin{array}{l}\mathrm{CA} \\
\mathrm{EF} \\
\mathrm{SA}\end{array}$ & $\begin{array}{l}1.000 \\
1.000 \\
1.000\end{array}$ & & & $\begin{array}{l}- \\
- \\
-\end{array}$ & $\begin{aligned} & 0.051 \\
& 1.000 \\
&<0.001^{*}\end{aligned}$ & & $\begin{aligned} & 0.028^{*} \\
< & 0.001^{*} \\
& 0.266\end{aligned}$ & $\begin{aligned} & 0.001^{*} \\
< & 0.001^{*} \\
< & 0.001^{*}\end{aligned}$ & $\begin{array}{l}<0.001^{*} \\
<0.001^{*} \\
<0.001^{*}\end{array}$ \\
\hline $17 \%$ EDTA & $\begin{array}{l}\mathrm{CA} \\
\mathrm{EF} \\
\mathrm{SA}\end{array}$ & $\begin{array}{l}0.051 \\
1.000 \\
0.001^{*}\end{array}$ & & $\begin{array}{l}0.051 \\
1.000 \\
0.001 *\end{array}$ & $\begin{array}{c}0.051 \\
1.000 \\
<0.001^{*}\end{array}$ & $\begin{array}{l}- \\
- \\
-\end{array}$ & $\begin{array}{l}0.570 \\
1.000 \\
0.001^{*}\end{array}$ & $\begin{array}{r}1.000 \\
<0.001^{*} \\
0.020^{*}\end{array}$ & $\begin{array}{c}0.091 \\
<0.001 * \\
0.998\end{array}$ & $\begin{array}{r}0.004^{*} \\
<0.001^{*} \\
0.708\end{array}$ \\
\hline $\begin{array}{c}0.5 \% \\
\mathrm{NaOCl}\end{array}$ & $\begin{array}{l}\mathrm{CA} \\
\mathrm{EF} \\
\mathrm{SA}\end{array}$ & $\begin{array}{l}0.693 \\
1.000 \\
1.000 \\
\end{array}$ & & & $\begin{array}{l}0.693 \\
1.000 \\
1.000 \\
\end{array}$ & $\begin{array}{l}0.570 \\
1.000 \\
0.001^{*}\end{array}$ & - & $\begin{array}{c}0.361 \\
<0.001 * \\
0.266\end{array}$ & $\begin{aligned} & 0.005^{*} \\
&< 0.001^{*} \\
&< 0.001^{*} \\
&\end{aligned}$ & $\begin{array}{l}<0.001^{*} \\
<0.001^{*} \\
<0.001^{*}\end{array}$ \\
\hline $\begin{array}{c}1.0 \% \\
\mathrm{NaOCl}\end{array}$ & $\begin{array}{l}\mathrm{CA} \\
\mathrm{EF} \\
\mathrm{SA}\end{array}$ & $\begin{array}{c}0.028^{*} \\
<0.001^{*} \\
0.266\end{array}$ & $\begin{aligned} & 0.028^{*} \\
&< 0.001^{*} \\
& 0.266\end{aligned}$ & $\begin{array}{r}0.028^{*} \\
<0.001^{*} \\
0.266\end{array}$ & $\begin{array}{r}0.028^{*} \\
<0.001^{*} \\
0.266\end{array}$ & $\begin{array}{l}1.000 \\
0.001^{*} \\
0.020 *\end{array}$ & $\begin{array}{c}0.361 \\
<0.001^{*} \\
0.266\end{array}$ & $\begin{array}{l}- \\
- \\
-\end{array}$ & $\begin{aligned} & 0.165 \\
< & 0.001^{*} \\
& 0.007^{*}\end{aligned}$ & $\begin{array}{r}0.008^{*} \\
<0.001^{*} \\
0.002^{*}\end{array}$ \\
\hline $\begin{array}{c}2.5 \% \\
\mathrm{NaOCl}\end{array}$ & $\begin{array}{l}\mathrm{CA} \\
\mathrm{EF} \\
\mathrm{SA}\end{array}$ & $\begin{aligned} & 0.001^{*} \\
&< 0.001^{*} \\
&< 0.001^{*} \\
&\end{aligned}$ & $\begin{aligned} & 0.001^{*} \\
&< 0.001^{*} \\
& 0.157\end{aligned}$ & $\begin{aligned} & 0.001^{*} \\
< & 0.001^{*} \\
< & 0.001^{*}\end{aligned}$ & $\begin{aligned} & 0.001^{*} \\
&< 0.001^{*} \\
&< 0.001^{*} \\
&\end{aligned}$ & $\begin{aligned} & 0.091 \\
< & 0.001 * \\
& 0.998\end{aligned}$ & $\begin{aligned} & 0.005^{*} \\
&< 0.001^{*} \\
&< 0.001^{*} \\
&\end{aligned}$ & $\begin{aligned} & 0.165 \\
< & 0.001^{*} \\
& 0.007^{*}\end{aligned}$ & $\begin{array}{l}- \\
- \\
-\end{array}$ & $\begin{aligned} & 0.528 \\
&< 0.001^{*} \\
& 0.975\end{aligned}$ \\
\hline $\begin{array}{l}5.25 \% \\
\mathrm{NaOCl}\end{array}$ & $\begin{array}{l}\mathrm{CA} \\
\mathrm{EF} \\
\mathrm{SA}\end{array}$ & $\begin{array}{l}<0.001^{*} \\
<0.001^{*} \\
<0.001^{*}\end{array}$ & $\begin{aligned} &<0.001^{*} \\
&<0.001^{*} \\
& 0.581\end{aligned}$ & $\begin{aligned} & 0.001^{*} \\
< & 0.001^{*} \\
< & 0.001^{*}\end{aligned}$ & $\begin{array}{l}<0.001^{*} \\
<0.001^{*} \\
<0.001^{*}\end{array}$ & $\begin{aligned} & 0.004^{*} \\
&<0.001^{*} \\
& 0.708\end{aligned}$ & $\begin{array}{l}<0.001^{*} \\
<0.001^{*} \\
<0.001^{*}\end{array}$ & $\begin{array}{r}0.008^{*} \\
<0.001^{*} \\
0.002^{*}\end{array}$ & $\begin{aligned} & 0.528 \\
< & 0.001^{*} \\
& 0.975\end{aligned}$ & $\begin{array}{l}- \\
- \\
-\end{array}$ \\
\hline
\end{tabular}

*Values of statistical significance $(\mathrm{p}<0.05)$. C $(-)$ and $\mathrm{C}(+)$ are respectively related to microorganisms which were incubated in root canal irrigant-depleted medium $(-)$ or PBS $(+)$ before cultivation in $\mathrm{BHI}$ medium.

Table 3 - Metabolic activity of the microorganisms before $[C(-)]$ and after their incubation with different concentrations (\%) of EDTA or $\mathrm{NaOC}$

\begin{tabular}{c|c|c|c|c|c|c}
\hline \multirow{2}{*}{ Microorganisms } & \multicolumn{7}{|c|}{ Irrigant solution } \\
\cline { 2 - 7 } & $\mathrm{C}(-)$ & $\begin{array}{c}17 \% \\
\text { EDTA }\end{array}$ & $\begin{array}{c}0.5 \% \\
\mathrm{NaOCl}\end{array}$ & $\begin{array}{c}1.0 \% \\
\mathrm{NaOCl}\end{array}$ & $\begin{array}{c}2.5 \% \\
\mathrm{NaOCl}\end{array}$ & $\begin{array}{c}5.25 \% \\
\mathrm{NaOCl}\end{array}$ \\
\hline Candida albicans & 0.0015 & 0.0170 & 0.0370 & 0.0065 & 0.0095 & 0.0040 \\
\hline Enterococcus faecalis & 0.0080 & NA & NA & 0.0460 & 0.0225 & 0.0045 \\
\hline Staphylococcus aureus & 0.0305 & 0.0015 & NA & 0.0010 & 0 & 0 \\
\hline
\end{tabular}

No significant $(p<0.05)$ differences could be seen between groups. Numbers represent the diameters of the inhibition zones. $\mathrm{NA}=$ not applicable (In these cases, inhibition zones were not formed in the diffusion agar test, so the metabolic activity test was not applicable). C $(-)=$ Negative control microorganism.

Chelate and acidic solutions, including EDTA and citric acid, have been recommended for removing the smear layer from instrumented root canals. ${ }^{16}$
In the present study, the EDTA solution presented lack of microbicidal activity against Enterococcus faecalis, corroborating the findings obtained by Arias-Miliz and Ferrer Luque. ${ }^{16}$ By contrast, the 
Graph 1 - Metabolic activity of Candida albicans, Enterococcus faecalis and Staphylococcus aureus after their incubation for $24 \mathrm{~h}$ with EDTA and $\mathrm{NaOCl}$.

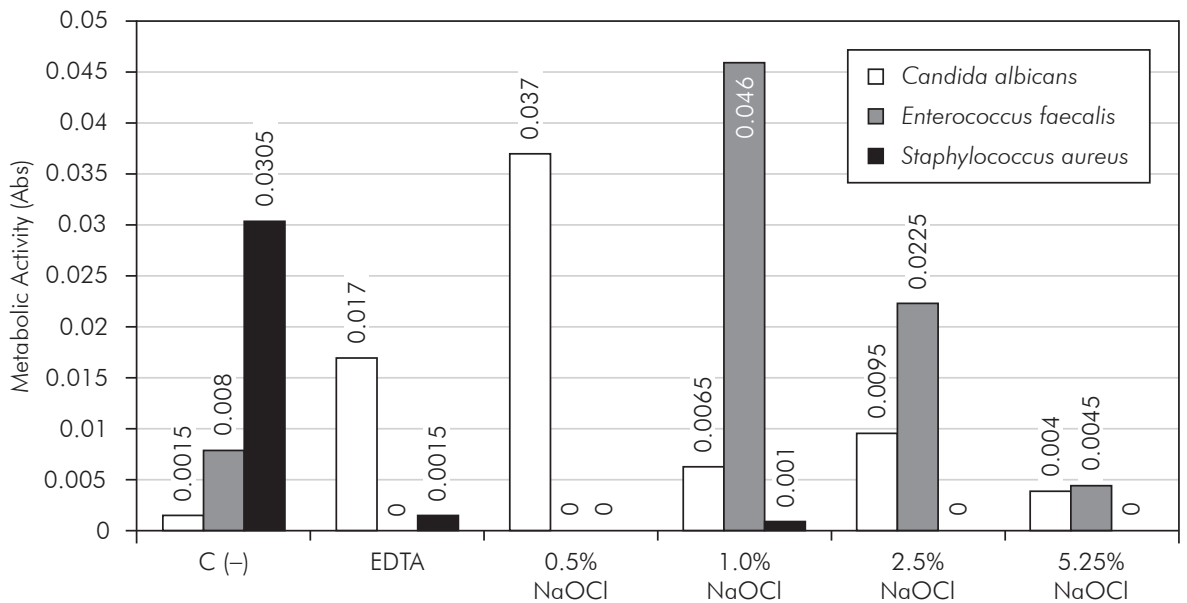

same authors showed an inhibition zone using 10\% citric acid against Enterococcus faecalis. Although citric acid presents low cytotoxity as an advantage, ${ }^{17}$ in the present study, $6 \%$ and $10 \%$ citric acid did not form any inhibition zone against any of the microorganisms tested. In agreement with Grawehr et al., ${ }^{18}$ the current study demonstrated that $17 \%$ EDTA was more effective than $0.5 \% \mathrm{NaOCl}$ against Candida albicans and Staphylococcus aureus. The maintenance of microorganisms in contact with EDTA over a prolonged period is as lethal as short periods of contact, increases the permeability of the outer membrane to hydrophobic molecules, and improves the action of antibacterial agents. ${ }^{19}$ Branin at al, ${ }^{20}$ reported that the metal chelator EDTA is known to have activity against biofilms of gram-positive bacteria such as Staphylococcus aureus.

The agar diffusion test does not distinguish microbiostatic and microbicidal properties of dental materials neither does it provide any information about the microorganisms viability after the test. ${ }^{21}$ The bacteria around the inhibition zone might grow back after some days. In clinical practice, it may be possible that after contact with root canal irrigants, microorganisms could still remain viable; this would depend on the irrigant and its concentration. For that reason it is important to associate the metabolic activity to the agar diffusion test, when evaluating the inhibitory activity of root canal irrigants.

Even after irrigation of the root canal with an antimicrobial solution, it may not be possible to eliminate all microorganisms from the root canal. ${ }^{22}$
The microorganisms may multiply rapidly in 2-4 days, almost returning to their original numbers, if the canal is not filled with an antimicrobial substance between visits. ${ }^{12}$ In the present study, a low metabolic activity that was not statistically significant was noted. Perhaps the low activity could be explained by the short period of incubation, since the metabolic activity was evaluated after only $24 \mathrm{~h}$. More studies are necessary to evaluate metabolic activity after longer periods. The high $\mathrm{pH}$ of $\mathrm{NaOCl}$ interferes in cytoplasmatic membrane integrity with irreversible enzymatic inhibition, biosynthetic alterations in cell metabolism and phospholipids destruction, ${ }^{9}$ and probably $24 \mathrm{~h}$ was not sufficient to allow bacteria recuperation, the same occurred with 17\% EDTA against Candida albicans and Staphylococcus aureus.

In the inhibition zone test, Candida albicans, Enterecoccus faecalis and Staphylococcus aureus were sensitive to $1 \% \mathrm{NaOCl}$ and higher concentrations. However, only 2.5 and $5.25 \% \mathrm{NaOCl}$ were confirmed as microbicidal irrigants for Staphylococcus aureus after the metabolic activity test. The association of the two tests demonstrated that the other irrigants tested had a microbiostatic effect against Candida albicans and Enterecoccus faecalis. These results suggest that microorganism eradication in an endodontic infection may be obtained in association with other measures such as intracanal medication between sessions. Moreover, the results obtained by association of the two tests demonstrated the importance of the metabolic activity test as a complemen- 
tary test to assess antimicrobial properties of root canal irrigants.

The present results support an initial hypothesis that there is a metabolic activity around the inhibition zone after the inhibition test, although without statistical significance. The short period of incubation may contribute to this result. Further studies are necessary to evaluate metabolic activity over a prolonged period.

\section{Conclusion}

Citric acid did not present antimicrobial activity. Only $2.5 \%$ and $5.25 \% \mathrm{NaOCl}$ presented antimicro-

\section{References}

1. Siqueira Jr JF. Endodontic infections: concepts, paradigms, and perspectives. Oral Surg Oral Med Oral Pathol Oral Radiol Endod. 2002 Sep;94(3):281-93.

2. Siqueira Jr JF, Rocas IN. Polymerase chain reaction-based analysis of microorganisms associated with failed endodontic treatment. Oral Surg Oral Med Oral Pathol Oral Radiol Endod. 2004 Jan;97(1):85-94.

3. Abou-Rass M, Piccinino MV. The effectiveness of four clinical irrigation methods on the removal of root canal debris. Oral Surg Oral Med Oral Pathol. 1982 Sep;54(3):323-8.

4. D’Arcangelo C, Di Nardo Di Maio F, Stracci N, Spoto G, Malagnino VA, Caputi S. Pulp-dissolving ability of several endodontic irrigants: a spectrophotometric evaluation. Int J Immunopathol Pharmacol. 2007 Apr;20(2):381-6.

5. Nudera WJ, Fayad MI, Johnson BR, Zhu M, Wenckus CS, Begole EA, et al. Antimicrobial effect of triclosan and triclosan with Gantrez on five common endodontic pathogens. J Endod. 2007 Oct;33(10):1239-42.

6. Oliveira DP, Barbizam JV, Trope M, Teixeira FB. In vitro antibacterial efficacy of endodontic irrigants against Enterococcus faecalis. Oral Surg Oral Med Oral Pathol Oral Radiol Endod. 2007 May;103(5):702-6.

7. Siqueira Jr JF, Rocas IN, Santos SR, Lima KC, Magalhaes FA, de Uzeda M. Efficacy of instrumentation techniques and irrigation regimens in reducing the bacterial population within root canals. J Endod. 2002 Mar;28(3):181-4.

8. Fidalgo TKS, Barcelos R, Petrópolis DB, Azevedo BR, Primo LG, Silva FC. Citotoxidade de diferentes concentrações de hipoclorito de sódio sobre osteoblastos humanos. RGO (Porto Alegre). 2009 Jul;57(3):317-21.

9. Estrela C, Ribeiro RG, Estrela CR, Pecora JD, Sousa-Neto MD. Antimicrobial effect of $2 \%$ sodium hypochlorite and $2 \%$ chlorhexidine tested by different methods. Braz Dent J. 2003;14(1):58-62. bial activity against Staphylococcus aureus. In addition, $17 \%$ EDTA, $0.5 \%$ and $1 \% \mathrm{NaOCl}$ presented only microbiostatic activity against some of the microorganisms tested. The highest concentration of $\mathrm{NaOCl}(5.25 \%)$ presented superior antimicrobial activity when compared with other irrigants used.

\section{Acknowledgements}

The authors would like to thank Dr. Catarina Akiko Miyamoto from CNRMN-UFRJ for reviewing this manuscript, for grammar and style. This study was supported by the following Brazilian agencies: FUJB-UFRJ, FAPERJ and INPeTAm.

10. Mariscal A, Lopez-Gigosos RM, Carnero-Varo M, FernandezCrehuet J. Fluorescent assay based on resazurin for detection of activity of disinfectants against bacterial biofilm. Appl Microbiol Biotechnol. 2009; 82(4): 773-8311.

11. American Academy of Pediatric Dentistry. Guideline on pulp therapy for primary and young permanent teeth. Pediatr Dent. 2004;26(7 Suppl):115-9.

12. Bystrom A, Sundqvist G. Bacteriologic evaluation of the effect of 0.5 percent sodium hypochlorite in endodontic therapy. Oral Surg Oral Med Oral Pathol. 1983 Mar;55(3):307-12.

13. Segura JJ, Calvo JR, Guerrero JM, Jimenez-Planas A, Sampedro C, Llamas R. EDTA inhibits in vitro substrate adherence capacity of macrophages: endodontic implications. J Endod. 1997 Apr;23(4):205-8.

14. Garberoglio R, Becce C. Smear layer removal by root canal irrigants. A comparative scanning electron microscopic study. Oral Surg Oral Med Oral Pathol. 1994 Sep;78(3):359-67.

15. Gomes BP, Ferraz CC, Vianna ME, Berber VB, Teixeira FB, Souza-Filho FJ. In vitro antimicrobial activity of several concentrations of sodium hypochlorite and chlorhexidine gluconate in the elimination of Enterococcus faecalis. Int Endod. J 2001 Sep;34(6):424-8.

16. Arias-Moliz MT, Ferrer-Luque CM, Espigares-Rodriguez E, Liebana-Urena J, Espigares-Garcia M. Bactericidal activity of phosphoric acid, citric acid, and EDTA solutions against Enterococcus faecalis. Oral Surg Oral Med Oral Pathol Oral Radiol Endod. 2008 Aug;106(2):84-9.

17. Guimarães LF, Fidalgo TK, Menezes GM, Primo LG, SilvaFilho FC. Effects of citric acid on cultured human osteoblastic cells. Oral Surg Oral Med Oral Pathol Oral Radiol Endod. In press 2010.

18. Grawehr M, Sener B, Waltimo T, Zehnder M. Interactions of ethylenediamine tetraacetic acid with sodium hypochlorite in aqueous solutions. Int Endod J. 2003 Jun;36(6):411-7. 
- Inhibitory activity of root canal irrigants against Candida albicans, Enterococcus faecalis and Staphylococcus aureus

19. Nikaido H. Molecular basis of bacterial outer membrane permeability revisited. Microbiol Mol Biol Rev. 2003;67(4):593656.

20. Banin E, Brady KM, Greenberg EP. Chelator-induced dispersal and killing of Pseudomonas aeruginosa cells in a biofilm. Appl Environ Microbiol. 2006 Dec;72(3):2064-9.
21. Estrela C, Estrela CRA, Bammann LL, Pecora JD. Two methods to evaluate the antimicrobial action of calcium hydroxide paste. J Endod. $2001 \mathrm{Dec} ; 27(12): 720-3$.

22. Bystrom A, Claesson R, Sundqvist G. The antibacterial effect of camphorated paramonochlorophenol, camphorated phenol and calcium hydroxide in the treatment of infected root canals. End Dent Traumatol. 1985 Oct;1(5):170-5. 